\title{
An Investigation on the Effect of Supply Chain Integration on Competitive Capability: An Empirical Analysis of Iranian Food Industry
}

\author{
Seyed Mahmood Hosseini (Assistant Professor) \\ Department of Business Administration, Faculty of Management and Accounting \\ Shahid Beheshti University, Tehran, Iran \\ E-mail: SM-Hosseini@sbu.ac.ir \\ Shahriar Azizi (Assistant Professor) \\ Department of Business Administration, Faculty of Management and Accounting \\ Shahid Beheshti University, Tehran, Iran \\ E-mail: s-azizi@sbu.ac.ir \\ Narges Sheikhi (Corresponding author) \\ MA in Business Administration, Faculty of Management and Accounting \\ Shahid Beheshti University, Tehran, Iran \\ E-mail: sheikhi.narges@gmail.com
}

Received: January 15, 2012

Accepted: February 2, 2012

Published: March 1, 2012

doi:10.5539/ijbm.v7n5p73

URL: http://dx.doi.org/10.5539/ijbm.v7n5p73

\begin{abstract}
In the current conditions of competitive market, companies shed light on not only their own organization's affairs, but also on the identification of other relevant resources and factors out of their organization to have appropriate reaction in facing with them. That is to utilize opportunities to gain competitive advantages and enhance their level of competitive capability. The key concern in a supply chain is to coordinately managing and controlling of all the primary and support activities of the company that will be achieved with an appropriate integration of supply chain. In fact, having an integrated approach to the processes, internal and external, and emphasis on win-win approach instead of negotiating approach between elements of the chain are the most important issues in supply chain integration context.

This study investigates the impact of supply chain integration on competitive capability. According to the findings of the study, supply chain integration has direct positive influence on competitive capability. In more depth, integration with suppliers has direct negative impact on competitive capability elements of cost leadership and differentiation. Internal integration has no direct impact on competitive capability. On the other hand, internal integration influences on cost leadership and differentiation indirectly through integration with suppliers and integration with customers. So, it can be resulted from findings that internal integration as a foundation for supply chain integration has direct influence on integration with supply chain partners, suppliers and customers, and eventually, results in improvement of competitive capabilities of the organization.
\end{abstract}

Keywords: Supply chain integration, Integration with suppliers, Internal integration, Integration with customers, Competitive capability, Cost leadership, Differentiation

\section{Introduction}

Nowadays, this is critical for organizations to have cooperative relationship with other members of supply chain in order to response customer needs and market demands. So, the level of competitiveness of the organization is influenced by the activities of other elements of supply chain. Supply chain includes all activities and processes 
relevant to stream of producing and trading products and services from raw material to final product. These include information and money as well as material (Handfield \& Nichols, 1999). In recent years, the competition is between supply chains instead of companies as unit. It means, the companies should be aware of their integration with suppliers and customers as well as concentrate on their internal activities.

In this research, we will test the influence of supply chain integration on competitive capability and investigate the strategic role of supply chain integration in improvement of competition capabilities. So, it will be possible to link the company's supply chain integration strategy with its competition strategy to offer a set of useful strategies. Also, we will evaluate the impact of every dimension of supply chain integration on every dimension of competitive capability. These relationships are presented in a conceptual model in detail.

In fact, the main questions of this research are:

How is the impact of supply chain integration on competitive capability? How is the impact of every dimension of supply chain integration on competition capability of cost leadership and differentiation?

\section{Theoretical Background and Literature Review}

Creating capabilities to gain and retain competitive advantage was the core of activities and strategies of managers in recent century. At the beginning, the economists with offering concepts like absolute and relative advantage, cost and demand functions, and theory of markets were pioneers in the concept and presented the importance of recognizing economic relations and regulations in designing strategies. The economic analyses were based on countries and nations, but the managers are interested in competitive advantages for companies and organizations. So, the theories have been presented by management scientists were different from the economists' ones. For example the concepts of experiment curve and learning curve were presented after WWII in order to reduce the cost of goods sold (CoGS). These concepts were different from the classic theories and described CoGS as a function of scale of production. According to studies, a two time increasing of experiment, the CoGS decreased by 20-30 percent. Learning curve emphasized on human resource productivity and presented that by improving quality of work done by human resource and reducing work times CoGS would be reduced by 10-15 percent. On the other hand, specialty orientation results in savings in time and works. These theories mainly mean that even with respect to inflation, in order to be survived in competition environment, the CoGS should be reduced. These approaches have been considered in Japanese companies and resulted in growth of their markets and reduction of CoGS of their products because they have succeeded in utilizing experiment and learning curves to reduce cost of goods sold.

From then, there were many theories and techniques in area of competition and factors influencing create and retain competitive capability and supply chain management is one of the latest and most important tools has been presented in modern age. According to CSCMP (Council of Supply Chain Management Professionals), Supply chain management encompasses the planning and management of all activities involved in sourcing and procurement, conversion, and all logistics management activities. Importantly, it also includes coordination and collaboration with channel partners, which can be suppliers, intermediaries, third party service providers, and customers. This approach with emphasis on integration and cooperation between all involved sides in supply chain greatly influences on waste reduction, delivery speed increase, unit costs reduction, and flexible response to needs of market and makes it possible for managers to do actions dramatically better than competitors. Flynn et al. (2010) define supply chain integration as a limit to which a manufacturer works with its partners strategically, and manages internal and external processes in a participative manner. In fact, companies worked independent at the beginning of their launching try to have cooperation with other elements of supply chain in order to gain better competitive advantages. For instance, Lambert and Cooper (2000) presented that the success of a company increasingly depends on its management capabilities to integrate the network of trading relations and Porter mentions that the relationship between company's value chain and the ones of the company's suppliers provide growth opportunities to improve their own competitive advantage (Porter, 1998).

Also, we cannot consider this concept separately from relationship marketing involving areas like Customer Relationship Management (CRM), Supplier Relationship Management (SRM), and Demand Management (DM). Hunt et al. (2006) present that relationship marketing shelters companies in creating strategic group competition instead of individual. In other words, with concentration on relationship marketing, the company enables to have relationship with other members of supply chain with trust and commitment. This kind of integration and coordination make it possible for the supply chain of the company to achieve a sustainable competitive advantage. The process of growth and development of supply chain integration concept is gradual and is based on the following stages (Stevens, 1989):

- Autonomy of units: each unit makes its decisions and plans separately based on classical management 
style. The goal of managers is to maximize profitability. The process of being compatible with market is slow and innovative opportunities are rarely achieved.

- Limited integration: some similar tasks like purchasing, materials control, distribution, and inventory management are integrated to some extent. Services to customers are being improved gradually and the companies are to gain competitive advantages with internal integration of separate tasks.

- Internal integration: the structure is being changed from functional to product and process structure and internal integration is being considered. Considerable outcomes of this stage will be mid-term planning, coordinated administration in whole of the company, and optimized flow of information between the departments. System thinking will be institutionalized in offering services to customers in this level of integration.

- Supply chain integration development: the ultimate strategic objective of this level is vertical integration in supply chain. In this level, we have inter-organizational processes integrated as well as the organizations' internal processes, long-term relationships with supply chain partners are established, and long-term strategic planning is considered with the managers. Supply chain management (SCM) is in its summit at this level and relationship management is considered as well as logistics and information management, because SCM is the evolutionary outcome of inventory management and logistics.

Supply chain integration and competitive capability have been investigated empirically based on different approaches of different researchers and it will be useful to review the literature and then present the proposed conceptual model according to the works have been done and their critical findings.

The most important researches are since 2000 and every researcher has investigated the topic based on a specific model.

Lawrence and Lorsch (1986) define integration as the quality of cooperation between the departments that is essential for the company to gain unity as a matter of the environment. Their definition only considers internal integration like the work of Pagell (2004).

Vickery et al. (2003) have measured dimensions of having partnership with suppliers and closer relationships with customers as well as internal integration. They investigated the impacts of integrated supply chain strategy on customer services in the automotive industry of North America. Competitive capability is measured only with customer service variable in their work. According to the findings, supply chain integration has direct positive impact on customer service.

Rosenzweig et al. (2003) investigated the impact of integration strategies on competitive capability of the company with respect to manufacturers of consumer products in zones such as North America, Europe, Asia-Pacific, and Latin America. They have measured competitive capability with 4 variables of product quality, delivery reliability, process flexibility, and cost leadership. Supply chain integration is defined in 4 levels of close internal integration, close integration with material suppliers, close integration with distributors/retailers, and close integration with customers. According to the findings, manufacturers with high level integration have better conditions of product quality, delivery reliability, process flexibility, and cost leadership.They also measured the impact of size as a control variable. High level integration with respect to the size variable leads to improved measures of competitive capability dimensions.

These findings are more comprehensive than the former as a matter of two dimensions; first, they added close integration with distributors/retailers to the dimensions of supply chain integration. Second, the variables of competitive capability are mainly different from the Vickery' work (2003). The impact of this development of the concepts of supply chain integration and competitive capability can be observed in later researches. For example, Swink et al. (2007) evaluated the impact of supply chain integration on competitive capabilityin different industries of North America more or less with such measures, but their findings were different. They investigated supply chain integration based on 4 dimensions of strategic integration with customers, strategic integration with suppliers, product-process technology integration, and corporate strategy integration; and competitive capability with 5 dimensions of cost, quality, delivery, process flexibility, and new product flexibility. Findings show that integration with suppliers and integration with customers have no significant relationship with competitive capabilities. Corporate strategy integration and product-process integration seem to be stronger drivers to manufacturing capability development compared to other kinds of strategic integration.

Studies have been done in years of 2009 and 2010 mainly emphasis on three critical dimension of supply chain:

- Integration with suppliers 
- Internal integration

- Integration with customers

According to these researches, companies with more developed supply chain have significant differentiation with the ones with less developed supply chain. Here we have mentioned five researches of these years and their findings briefly.

Kim (2009) investigated the impact of the level of integration on company's competitive capability. Supply chain integration has been measured based on three dimensions of internal integration, integration with suppliers and integration with customers; and competitive capability has been evaluated with four variables of cost leadership, customer service, innovative marketing technology, and differentiation. According to the findings of the work with investigating a wide range of Japanese and Korean companies in different industries, supply chain integration leads to competitive capabilities in Japanese companies and these capabilities affect the company's performance in relation with supply chain operational capability. While, in Korean companies with smaller sizes competitive capabilities in relation with supply chain operational capability lead to supply chain integration and affect the company's performance.

Oghazi (2009) investigates the relationship between supply chain integration and competitive capabilities of manufacturing companies in different industries of Sweden. Similar to dimensions of Kim (2009), in this work supply chain integration is measured in three dimensions: integration with suppliers, integration with customers, and internal integration. The variables have been used to measure competitive capabilities were cost leadership, customer service, innovative marketing, differentiation, and focus strategy. Findings show that supply chain integration influences on competitive capabilities positively. Also, company size has been used as a control variable and no significant impact have been observed.

Hosseini Baharanchi (2009) investigated the relationship between different aspects of supply chain integration and some characteristics of the product (quality and innovation) in the automotive industry of Iran, and the findings were different from the literature. Integration is measured by internal integration, integration with suppliers, and integration with customers and product characteristics are measured in two aspects of quality and innovation. Findings showed that integration with suppliers and customers influences on products quality and innovation positively. Companies need to be integrated more with suppliers in order to have more performance in product quality, but for concentration on product innovation it would be more effective to emphasis on integration with customers. Internal integration has the weakest relationship compared to other aspects of integration with product quality and has very weak relationship with product innovation. It means that in the area of product quality, affecting variables by order of impact are integration with suppliers, integration with customers, and internal integration, but in the area of product innovation integration with customers and then integration with suppliers are influencing and internal integration has no influence. It seems that internal integration is a pre-assumption for the impact of integration activities on product quality and innovation. Results of data analyses show that companies mostly make decisions of integration in their supply chain in order to gain high performance in innovation and product quality. It should be mentioned that qualitative performance has been considered with these companies more than product innovation.

Feng et al. (2010) investigated the impact of participation with suppliers and customers on competitive advantage as a matter of external integration with concentration on resource-based view (RBV) and knowledge-based view (KBV). They have done the investigation in different industries in China. Competitive capability has been measured by means of product quality, cost leadership, delivery reliability, process flexibility, and customer service and size of company and type ownership have been considered as control variables. Their findings show that participation with customers has significant influence on product quality, delivery reliability, process flexibility, and customer service, but no influence on cost leadership. Participation with supplier has significant influence on cost leadership, but has no influence on product quality, delivery reliability, process flexibility, and customer service. Also they have found out that private sector companies do better in delivery reliability, process flexibility, and customer service compared to public sector companies, but public sector companies have advantage in cost leadership relative to others.

Results of previous studies about the overall impact of supply chain integration on competitive capabilities are exhibited in Table 1.

Insert Table 1 here

With an overall view of the literature, it can be mentioned that supply chain integration has direct impact on competitive capabilities (Swink et al., 2007; Feng et al., 2010), but in detail, some aspects of supply chain 
integration have no significant impact on some aspects of competitive capabilities. Also, some aspects have greater impact on competitive capabilities compared to others (Hosseini Baharanchi, 2009).

Following literature review leads to identify dimensions of research variables that had been empirically examined previously and found to be statistically significant by other researches.

a) Supply chain integration

Totally, different aspects have been presented by researchers for investigating supply chain integration. Some researchers have concentrated only on external integration of supply chain, integration with suppliers and customers (Feng et al., 2010; Frohlich and Westbrook, 2001). But three aspects of integration including integration with suppliers, internal integration, and integration with customers are more popular (Kim, 2006, 2009; Narasimhan \& Kim, 2002; Oghazi, 2009; Hosseini Baharanchi, 2009; Vickery et al., 2003; Flynn et al., 2010; Zailani and Rajagopal, 2005). Internal and external integration have different roles in supply chain integration. Internal integration coordinates internal operations and processes appropriately and brings them together as a consonant whole while the external integration is to establish close occasions based on cooperation with suppliers and customers. After all, with respect to these differences, the main objective of integration is to achieve mutually benefits for every component of supply chain. So, integration is examined based on the aspects of integration with suppliers, internal integration, and integration with customers.

b) Competitive capability

Competitive capability is measured by means of different indicators in previous studies (Feng et al., 2010; Kim, 2006, 2009; Hosseini Baharanchi, 2009; Oghazi, 2009; Mzoughi et al. 2008; Swink et al., 2007; Li et al., 2006; Rosenzweig et al., 2003; Vickery et al., 2003; Matanda and Schroder, 2002). We cannot see an agreement in these studies for determining aspects of competitive capabilities like such in supply chain integration literature and every study has its own arrangement of the aspects measuring competitive capabilities. Investigation of the literature of competitive capabilities in detail shows that cost leadership (Kim, 2006, 2009; Rosenzweig et al., 2003; Swink et al., 2007; Oghazi, 2009; Feng et al., 2010; Li et al., 2006) and differentiation (Kim, 2006, 2009; Oghazi, 2009; Hosseini Baharanchi, 2009) are used more than other indicators to measure competitive capabilities. So, according to the literature and Porter's generic strategic approach (1980), concentration on two strategies of cost leadership and differentiation will work well.

\section{Hypotheses Development and Conceptual Model}

This study is an empirical research on the variables mentioned in the literature about supply chain integration and competitive capability. So, following hypotheses create a clear picture of what will be investigated in this research.

\subsection{Research Hypotheses}

\subsubsection{The effect of supply chain integration on cost leadership}

Utilization of knowledge of suppliers and customers successfully enhances competitive capabilities of the company (Nambisan, 2002). Reviewing the literature shows that internal integration can lead to enhancement of the company's capability for cost reduction chain (Kim, 2009; Rosenzweig et al., 2003; Swink et al., 2007; Oghazi, 2009; Hosseini Baharanchi, 2009; Vickery et al., 2003; Feng et al., 2010). Fulconis and Pache (2005) conclude that supply chain plays the most important role for companies' competitiveness. Based on RBV and KBV, participation with suppliers helps companies provide value in cost management area (Feng et al., 2010). According to Handfield and Bechtel (2002), participation with suppliers as the first step to new product development is a way to strong utilization of the knowledge of suppliers in order to cost reduction and production time improvement. Most of the empirical studies concentrate on the impact of one of the aspects of supply chain integration, internal or external integration, on competitive capabilities of a business. In this study, we have focus on different dimensions of supply chain integration, internal integration, integration with suppliers, and integration with customers. Examination of the influence of supply chain integration on cost leadership capability is rarely performed in previous studies so, the following hypothesis is considered in this research:

$\mathrm{H}_{1}$ : the level of supply chain integration affects cost leadership capability.

Sub-hypotheses seek to further answer before coming up with the main hypothesis. Then, in this research we examine several sub-hypotheses as follows:

$\mathrm{H}_{1 \mathrm{a}}$ : integration with suppliers affects cost leadership capability.

$\mathrm{H}_{1 \mathrm{~b}}$ : internal integration affects cost leadership capability. 
$\mathrm{H}_{1 \mathrm{c}}$ : integration with customers affects cost leadership capability.

\subsubsection{The effect of supply chain integration on differentiation}

Supply chain integration makes it possible for the company to concentrate on special areas and its core competencies (Simchi-Levi et al., 2003). According to the literature, external integration with suppliers and customers enables companies to enhance their technical and logistics capabilities and affects their products' quality and differentiation (Kim, 2009; Rosenzweig et al., 2003; Swink et al., 2007; Oghazi, 2009; Hosseini Baharanchi, 2009; Vickery et al., 2003; Feng et al., 2010). Kaulio (1998) mentions that customer's participation in creation and development of a new product is a source of novel ideas. Also, according to Nambisan (2002), customers can participate in testing finished products, supporting company's products, and their continuous improvement as well as in process of novel ideas creation. On the other hand, Chang et al. (2006) have found through an empirical study that it is vital to have participation with suppliers and cooperation with them in order to improve supply chain effectiveness and company's competitiveness. Porter (1980) believes that customers and suppliers are drivers for competitiveness in an industry. So, the second hypothesis of this study is:

$\mathrm{H}_{2}$ : the level of supply chain integration affects differentiation competitive capability.

To further clarify this hypothesis, the following sub-hypotheses are considered:

$$
\begin{aligned}
& \mathrm{H}_{2 \mathrm{a}} \text { : integration with suppliers affects differentiation capability. } \\
& \mathrm{H}_{2 \mathrm{~b}} \text { : internal integration affects differentiation capability. } \\
& \mathrm{H}_{2 \mathrm{c}} \text { : integration with customers affects differentiation capability. }
\end{aligned}
$$

\subsection{The Research Model: Supply chain integration on competitive capability}

The aim of this research is to determine the impact of different aspects of supply chain integration on different aspects of company's competitive capabilities. Different factors have been investigated by previous works about supply chain integration variable (Feng et al., 2010; Flynn et al., 2010; Hosseini Baharanchi, 2009; Kim, 2006, 2009; Oghazi, 2009; Swink et al., 2007; Zailani and Rajagopal, 2005; Vickery et al., 2003; Rosenzweig et al., 2003; Frohlich and Westbrook, 2001). This variable can be studied as matter of different aspect that three aspects of integration with suppliers, internal integration, and integration with customers are more in literature and will be the basis of this research too.

On the other hand, Porter (1980) presents three generic strategic approaches for a company's excellence: cost leadership, differentiation, and focus. Competitive advantage comes out from each strategy and the company's true choice of each strategy, with respect to the area of business and the kind of advantage considered, will lead to gain competitive advantage for the company (Porter, 1998). So, cost leadership and differentiation can be investigated in this research because in focus strategy one of the other strategies or both of them will be considered.

\section{Insert Figure 1 here}

As exhibited in conceptual model in Figure 1, in this study we will investigate the impact of different levels of integration with suppliers, internal integration, and integration with customers on competitive capabilities of cost leadership and differentiation.

\section{Research Methodology}

\subsection{Instrument development and data collection}

In order to measure the content validity of the instrument, as a matter of different aspects of the research variables the questionnaire is appropriately based on theories and their practical applications in research. Target population of this study is the companies in food industry and so, the indicators of the questionnaire are related to food industry. In order to gain face validity, the primary questionnaire, with 50 questions, has been presented to 3 professors and 6 executive managers in mentioned industry to examine the questions' relevance, order, clarity, and intelligibility. Their main advice was to ask about only one indicator and make the questions as short as possible. So, some questions have been omitted and some have been modified according to the experts and their proposed comments.

The modified questionnaire has been confirmed after final interview with the experts. So, the primary questionnaire with 27 questions has been used in pre-test in a sample of 20 companies. The executive managers of the sample companies were requested to report vague, repeated, and irrelevant questions as well as to answer the questionnaire and to give their suggestions about the framework of the questions. 
The final questionnaire has been designed based on these feedbacks and has been sent to the respondents in form of Self-administered paper-based, electronic, fax, and incorporate with interview. The companies of respondents were average and large in size (with more than 50 staffs) because, the concept of supply chain management and integration makes sense only in companies with appropriate size. The respondent managers included chief executive officer, chairman, technical and quality manager, business administrator, and the factory manager with at least five years of experience in that position of the company. Also, in order to increase the reliability of the study, the respondents were requested to consult with other experienced managers in case of ambiguity. The responses were almost with honesty and enthusiasm because they were peculiar to the results of survey. At last, 275 questionnaires have been distributed between active companies in food industry and then we received 86 complete questionnaires.

Cronbach'scoefficient alpha retest method is used for reliability measurement of the instrument. As is mentioned in Table 2, Cronbach's alpha for the whole questionnaire is 0.97 that is more than 0.7 (Nunnally, 1978; Netemeyer et al., 2003).

Insert Table 2 here

Also, this index for both variables of the study is more than 0.7 too. It means that the respondents' perceptions from the questions are the same to some extent so; the research measurement tool is reliable.

\subsection{Measurements of Research Variables}

Previous researches have been reviewed to investigate different aspects of research variables. Different indicators that are considerable for researches have been identified and modified through interviewing with professors and executives. Final indicators have been used in questionnaire are exhibited in Table 3.

Insert Table 3 here

\section{Data Analysis}

\subsection{Confirmatory factor analysis}

For testing measurement models and being sure about their truth confirmatory factor analysis is used and the results are exhibited in Table 4. Load factors for the variables are between 0.35 and 0.94 .so, every observed variable has correlation with its own latent variable in an appropriate level.

\section{Insert Table 4 here}

Fitting indicators of the measurement model of the variables are relatively appropriate has been exhibited in Table 5.

\section{Insert Table 5 here}

In order to more detail investigation of the convergent validity of the constructs, CR and AVE are calculated by means of standard load factors of CFA (Fornell and Larcker, 1981), and are been exhibited in Table 4. There are different views about threshold of CR. Bagozzi and Yi (1988) emphasis on 0.6, but chin (1998) and Kim (2009) suggest 0.7 . The amount of this kind of validity for all variables is more than 0.7 and the threshold in this study is considered as 0.7. On the other hand, AVE is more than 0.5 for both of the variables. Fornell and Larcker (1981) mention this amount as an acceptable level. So, with respect to the amounts of CR and AVE we can say the instrument of the research has convergent construct validity.

Squared inter-correlation coefficient of the variables with AVE and CR are compared in order to examination of discriminant validity (Fornell and Larcker, 1981; Merschmann and Thonemann, 2010). As is shown in Table 6, the amounts for these indicators are more than the squared inter-correlation coefficient between variables so, the discriminant validity of the instrument is appropriate. It means that the variables are different from each other and measure separate concepts.

\section{Insert Table 6 here}

\subsection{Descriptive statistics}

Sample of the survey was from companies of food industry in Tehran including $25 / 4 \%$ from dairy products, $23 / 9 \%$ from sugary products, $21 / 1 \%$ from drinks, $12 / 7 \%$ from canned products, $11 / 3 \%$ from meat products, and $5 / 6 \%$ from edible oils industry. Descriptive statistics and correlation matrix of elements of research variables are shown in Table 7. This table shows that research tool has predictive validity because according to correlation matrix, dimensions of supply chain integration have significant correlation with dimensions of competitive capability (Swink et al., 2007). 
Insert Table 7 here

\subsection{Testing the structural model}

Structural equation model (SEM) is used in order to examination of the relationships with LISREL software. So, the hypotheses are tested simultaneously based on the primary conceptual model.

The results are shown in Table 8. Significance factors of first and second hypotheses are more than their critical value (1.96). So, both of the main hypotheses are confirmed. It means that supply chain integration has direct positive influence on different dimensions of competitive capability (cost leadership and differentiation).

\section{Insert Table 8 here}

As exhibited in Figure 2, the impact of supply chain integration level is 0.86 on cost leadership capability and 0.73 on differentiation capability. It means that the effect of supply chain integration on cost leadership capability is more than on differentiation.

\section{Insert Figure 2 here}

All of Subsidiary hypotheses of research are investigated by means of structural equations method and the effects of each dimension of supply chain integration -integration with suppliers, internal integration, and integration with customers- on each dimension of competitive capability -cost leadership and differentiation- are measured.

Integration with suppliers has direct but negative influence on cost leadership and differentiation. Integration with customers positively affects cost leadership and differentiation. But, internal integration has no influence on competitive capabilities. These results are exhibited in Table 9.

\section{Insert Table 9 here}

The model of subsidiary hypotheses of the research is shown in Figure 3 and path coefficient of each subsidiary relationship is illustrated on it. According to these path coefficients, integration with customers has more direct influence on each of competitive capabilities.

\section{Insert Figure 3 here}

Previous researches show that internal integration is described as default for supply chain integration. In other words, internal integration provides bedrock in a company for integration with customers and suppliers (Hosseini Baharanchi, 2009; Zhao et al., 2011). So, new hypotheses are tested by means of structural equation models:

$$
\begin{aligned}
& \mathrm{H}_{3 \mathrm{a}} \text { : internal integration affects integration with suppliers. } \\
& \mathrm{H}_{3 \mathrm{~b}} \text { : internal integration affects integration with customers. }
\end{aligned}
$$

The results are shown in Table 10. Both of the hypotheses are supported based on significance factors of each hypothesis. It means that internal integration affects integration with customers and suppliers.

\section{Insert Table 10 here}

Final modified model of the research is exhibited in Figure 4. With respect to path coefficients have been described in Figure 4, influence of internal integration on integration with customers and suppliers is strongly supported.

\section{Insert Figure 4 here}

The final model will be like Figure 5. Internal integration affects integration with other partners of supply chain and through this path, affects competitive capabilities' different dimensions. In other words, the company should provide appropriate environment of integration with suppliers and customers by means of internal integration establishment. These activities eventually lead to enhancement of company's capability of cost leadership and differentiation as competitive capabilities and improvement of its competitive position in the market.

\section{Insert Figure 5 here}

\section{Discussion and managerial implications}

\subsection{The overall impact of supply chain integration on competitive capability}

Kim (2009) mentions that, in Japanese companies, the supply chain integration leads to competitive capabilities. Findings of Oghazi (2009) shows that supply chain integration has influence on competitive capabilities. Also, Vickery et al. (2003) mention that supply chain integration has influence on customer service according to their survey on automotive industry in United States. Chang et al. (2006) found through an empirical survey that participation with suppliers is essential for effectiveness improvement of supply chain and competitiveness. 
Swink et al. (2007) found that integration with suppliers and customers have no influence on competitive capabilities. Other dimensions of integration like corporate strategy's integration and process-product integration affect competitive capability that can be described internal integration.

According to our findings, supply chain integration has direct positive influence on competitive capability and is aligned with works of Kim (2009) in Japanese Companies, Oghazi (2009), Vickery et al. (2003), and Chang et al. (2006).But, it is inconsistent with the results of Swink's work (2007).

Therefore, findings of this research, like Oghazi's, are consistent with relationship marketing theory. This theory deals with "all marketing activities directed toward establishing, developing, and maintaining successful relational exchanges" (Morgan and Hunt, 1994). Supply chain integration provides an environment for the company so that it can benefit from its internal competencies, can be sponsored by key members of supply chain, and become competitive. Trust and commitment between company, its suppliers, and its customers lead to integration between them and create a network that mutually benefits for all members. In other words, integration helps company and its partners to extend their competitive capabilities and achieve sustainable competitive advantage.

\subsection{The impact of supply chain integration on cost leadership}

Rosenzweig et al. (2003) found that consumer products' manufacturers with high level of integration can gain better positions and opportunities in cost leadership. Findings of Fenget al. (2010) evidence that integration with suppliers affects cost leadership to some extent. They mention based on resource based view and knowledge based view that participation with suppliers can help the company to create value in process of cost management. Also, based on Handfield and Bechtel (2002), participation with suppliers as the initial steps of creation and development of a new product is a powerful method of suppliers' knowledge utilization in order to reduction of costs and work times.

Current research shows that supply chain integration influences on cost leadership capability that is consistent with works of Rosenzweig et al. (2003), Feng et al. (2010), and Handfield and Bechtel (2002).

\subsection{The impact of supply chain integration on differentiation}

Fenget al. (2010) mention that integration with customers has influences on product quality, delivery reliability, process flexibility, and customer service. According to findings of Simchi-Leviet al. (2003), supply chain integration provides for company the opportunity to concentrate on its core competencies. High level of supply chain integration leads to improvement of product quality, delivery reliability, and process flexibility (Rosenzweig et al., 2003). These aspects of competitive capability can be described as differentiation. Also, Hosseini Baharanchi (2009) describes that integration with suppliers and customers influence on product quality and innovation. According to his findings, product quality is more related with integration with suppliers and integration with customers has more effect on product innovation and internal integration has no influence on competitive capability.

Current research's results show that supply chain integration has direct positive influence on differentiation capability, and is consistent with works of Feng et al. (2010), Simchi-Leviet al. (2003), Rosenzweig et al. (2003), and Hosseini Baharanchi (2009).

Also, research findings show that internal integration has no effect on both competitive capabilities. This result is aligned with the findings of Hosseini Baharanchi (2009). On the other hand, the result of negative influence of supply chain integration on both competitive capabilities is aligned with the findings of Swink et al. (2007). They mention that over-integration with suppliers may have undesirable consequences. Das et al. (2006) mention according to their work's findings that having deviation from 'optimum level' of integration with suppliers affects negatively on company's performance. According to the theory of Agency, over-integration with suppliers expose companies to different problems like less motivation of suppliers to have high level of performance because they feel that they have strong border of security in their position and their trading benefits are assured for long time. Also, the opportunity of finding new more appropriate suppliers will be threatened (Swink et al., 2007).

In addition to theoretical contribution, this research aims at making a contribution to practice. In other words, the results should be considered by practitioners and managers since they provide empirical evidence for advantages derived from supply chain integration.

First, in the process of development of appropriate strategies for establishment of supply chain integration plans, it is essential for managers to pay special attention to the company's competitive capabilities and try to affect company's performance strongly by means of improvement of them. 
Second, integration with customers directly and positively influences on competitive capabilities so that cost leadership and differentiation capabilities can be improved. Customer orientation and satisfying their needs and wants innovatively can be lead to facilitate novel idea generation in order to cost reduction and product differentiation.

Third, Internal integration is not directly related with competitive capabilities. This variable affects competitive capabilities positively through integration with other partners of supply chain. In other words, in order to gain and improve competitive capabilities, companies should improve their internal processes' coordination. Such coordination leads to have integrated relationships with customers and suppliers.

\section{Study Limitation and Future Research}

An important concept in supply chain integration is information sharing with suppliers and customers. So, information technology will play a critical role in supply chain integration. Here we can mention problems and deficiencies of companies in using IT for achieving advantages of integration between different elements in supply chain. Also, Medium and large size companies have been investigated in this study because the concept of supply chain is meaningful in relationship with companies of appropriate size. It can be suggested for future researches to consider size as a control variable and measure its effect on findings. Companies with different sizes may have different competitive strategies that can be affected with supply chain integration strategies differently.

Additionally, results of this study shows that integration with suppliers has negative influence on competitive capability. More researches are needed to find out advantages and disadvantages of this kind of integration.

It should be mentioned that there is no organizational position of supply chain manager in Iranian companies. So for data gathering, chief manager referred us to relevant experienced executive managers and in some cases CEO has completed the questionnaire himself. So, validity and truth of the answers were dependent to the chief manager's point of view about respondent mangers.

\section{References}

Bagozzi, R. P., \& Yi, Y. (1988). On the evaluation of structural equation models. Journal of the Academy of Marketing Science, 16 (1): 74-94. http://dx.doi.org/10.1177/009207038801600107

Boon-itt, S., \& Paul, H. (2006). A study of supply chain integration in Thai automotive industry: a theoretical framework and measurement. Management Research News, 29 (4): 194-205. http://dx.doi.org/10.1108/01409170610665059

Chang, S., Chen, R., Lin, R., Tien, S., and Sheu, C. (2006). Supplier involvement and manufacturing flexibility. Technovation, 26(10). 1136-1146. http://dx.doi.org/10.1016/j.technovation.2005.09.010

Chin, W. (1998). The partial least squares approach to structural equation modeling, in Markoulides. G.A. (Ed.), Modern Methods for Business Research. Lawrence Erlbaum, Mahwah, NJ, 295-336. http://dx.doi.org/10.1016/j.aap.2008.12.010

Council of Supply Chain Management Professionals. [Online] Available: http://cscmp.org

Das, A., Narasimhan, R., \& Talluri, S. (2006). Supplier integration-finding an optimal configuration. Journal of Operations Management, 24 (5), 563-582. http://dx.doi.org/10.1016/j.jom.2005.09.003

Feng, T., Sun, L and Zhang, Y. (2010). The effects of customer and supplier involvement on competitive advantage: An empirical study in China. Industrial Marketing Management, 39, 1384-1394. http://dx.doi.org/10.1016/j.indmarman.2010.04.006

Flynn, B. B, Huo, B and Zhao, X. (2010). The impact of supply chain integration on performance: A contingency and configuration approach. Journal of Operations Management, 28, 58-71. http://dx.doi.org/10.1016/j.jom.2009.06.001

Fornell, C., and Larcker, D. F. (1981). Evaluating structural equation models with unobservable variables and measurement error. Journal of Marketing Research, 18 (1): 39-50. http://dx.doi.org/10.2307/3151312

Frohlich, M. T., and Westbrook, R. (2001). Arcs of integration: an international study of supply chain strategies. Journal of Operations Management, 19 (2), 185-200. http://dx.doi.org/10.1016/S0272-6963(00)00055-3

Fulconis, F., and Pache, G. (2005). Exploiting SCM as source of competitive advantage: the importance of cooperative goals revisited. Competitiveness Review: An International Business Journal, 15 (2). 92-100. http://dx.doi.org/10.1108/10595420510818740 
Handfield, R. B and Nichols, E. L. (1999). Introduction to Supply Chain Management. Upper Saddle River, NJ, Prentice-Hall.

Handfield, R. B., and Bechtel, C. (2002). The role of trust and relationship structure in improving supply chain responsiveness. Industrial Marketing Management, 36 31(4): http://dx.doi.org/10.1016/S0019-8501(01)00169-9

Hosseini Baharanchi, S.R. (2009). Investigation of the Impact of Supply Chain Integration on Product Innovation and Quality. Transaction E: Industrial Engineering, 16 (1), 81-89.

Hunt, S.D. Arnett, D.B., and Madhavaram, S. (2006). The explanatory foundations of relationship marketing theory. Journal of Business \& Industrial Marketing, $21 \quad$ (2): 72-87. http://dx.doi.org/10.1108/10610420610651296

Kaulio, M.A. (1998). Customer, consumer, and user involvement in product development: A framework and a review of selected methods. Total Quality Management, 9(1): 141-149. http://dx.doi.org/10.1080/0954412989333

Kim, S. W. (2006). The effect of supply chain integration on the alignment between corporate competitive capability and supply chain operational capability. International Journal of Operations \& Production Management, 26 (10): 1084-1107.,http://dx.doi.org/ 10.1016/j.omega.2004.08.002

Kim, S. W. (2009). An investigation on the direct and indirect effect of supply chain integration on firm performance. The International Journal of Production Economics, 119, 328-346. http://dx.doi.org/10.1016/j.ijpe.2009.03.007

Lambert, D. M., and Cooper, M. C. (2000). Issues in Supply Chain Management. Industrial marketing management, 29(1): 65-83. http://dx.doi.org/10.1016/S0019-8501(99)00113-3

Lawrence, P.R., and Lorsch, J. W. (1986). Organization and environment: Managing differentiation and integration. Boston, MA: Harvard Business School Press.

Li, S., Ragu-Nathan, B., Ragu-Nathan, T.S., and Rao, S. S. (2006). The impact of supply chain management practices on competitive advantage and organizational performance. The International Journal of Management Science, 34, 107 - 124. http://dx.doi.org/ 10.1016/j.omega.2004.08.002

Matanda, M., and Schroder, B. (2002). Environmental factors, supply chain capabilities and business performance in horticultural marketing channels. Journal of Chain and Network Science, 2 (1): 47-60. http://dx.doi.org/ 10.3920/JCNS2002.x017

Merschmann, U., and Thonemann, U. W. (2010). Supply Chain Flexibility, Uncertainty and Firm performance: An Empirical Analysis of German manufacturing Firms. International Journal of Production Economics, 130 (1): 43-53. http://dx.doi.org/ 10.1016/j.ijpe.2010.10.013

Morgan, R. M., and Hunt, S. D. (1994). The commitment-trust theory of relationship marketing. Journal of Marketing, (58): 20-38. http://dx.doi.org/10.2307/1252308

Mzoughi, N., Bahri, N., and Ghachem, M. S. (2008). Impact of Supply Chain Management and ERP on Organizational Performance and Competitive Advantages: Case of Tunisian Companies. Journal of Global Information Technology Management, 11 (3). 24.

Nambisan, S. (2002). Designing virtual customer environments for new product development: Toward a theory. Academy of Management Review, 27(3): 392-413.

Narasimhan, R., \& Kim, S.W. (2002). Effect of supply chain integration on the relationship between diversification and performance: evidence from Japanese and Korean firms. Journal of Operations Management, 20(3): 303-323. http://dx.doi.org/10.1016/S0272-6963(02)00008-6

Netemeyer, R.G., Bearden, W.O., and Sharma, S. (2003). Scaling procedures: issues and applications. Sage Publications. London.

Nunnally, J.C. (1978). Psychometric Theory. McGraw-Hill. New York. NY.

Oghazi, P. (2009). An Empirical study of Swedish Manufacturing Firms' Enterprise Systems Adoption. Supply Chain Integration, Competition Capability and Performance. Doctoral Thesis. Lulea University of Technology, Swedish, 1-203.

Pagell, M. (2004). Understanding the factors that enable and inhibit the integration of operations, purchasing and logistics. Journal of Operations Management, 22 (5): 459-487. http://dx.doi.org/10.1016/j.jom.2004.05.008 
Porter, M. E. (1980). Competitive Strategy: Techniques for Analyzing Industries and Competitors. New York: Free Press.

Porter, M. E. (1998). Competitive advantage. New York: The fress press.

Rosenzweig, E. D., Roth, A. V., and Dean J.W. (2003). The influence of an integration strategy on competitive capabilities and business performance: An exploratory study of consumer products manufacturers. Journal of Operations Management, 21, 437-456. http://dx.doi.org/ 10.1016/S0272-6963(03)00037-8

Simchi-Levi, D., \& Kaminsky, P. (2000). Designing and managing the supply chain. New York, Mc Graw Hill.

Stevens, G. S. (1989). Integrating the supply chain. International Journal of Physical Distribution and Material Management, 19 (8): 3-8. http://dx.doi.org/10.1108/EUM0000000000329

Swink, M., Narasimhan, R., and Wang, C. (2007). Managing beyond the factory walls: Effects of four types of strategic integration on manufacturing plant performance. Journal of Operations Management. 25, 148-164. http://dx.doi.org/ 10.1016/j.jom.2006.02.006

Vickery, S. K., Jayaram, J., Droge, C., and Calantone, R. (2003). The effects of an integrative supply chain strategy on customer service and financial performance: an analysis of direct versus indirect relationships. Journal of Operations Management, 21, 523-539. http://dx.doi.org/10.1016/j.jom.2003.02.002.

Wong, C. Y., and Boon-itt, S. (2008). The influence of institutional norms and environmental uncertainty on supply chain integration in the Thai automotive industry. The International Journal of Production Economics, 115. 400- 410. http://dx.doi.org/ 10.1016/j.ijpe.2008.05.012

Zailani, S., and Rajagopal, P. (2005). Supply chain integration and performance: US versus East Asian companies. Supply Chain Management: An International Journal, 10 (5): 379-393. http://dx.doi.org/10.1108/13598540510624205

Zhao, X., Huo, B., Selen, W., \& Yeung, J. H. Y. (2011). The impact of internal integration and relationship commitment on external integration. Journal of Operations Management, 29: 17-32. http://dx.doi.org/10.1016/j.jom.2010.04.004

Table 1. Empirical contributions in the effect of SCI on competitive capability

\begin{tabular}{|c|c|c|c|c|}
\hline Study & $\begin{array}{c}\text { Sample and } \\
\text { context }\end{array}$ & $\begin{array}{l}\text { Supply Chain } \\
\text { Integration }\end{array}$ & $\begin{array}{l}\text { Competitive } \\
\text { capability }\end{array}$ & Major findings \\
\hline $\begin{array}{l}\text { Vickery et } \\
\text { al.(2003) }\end{array}$ & $\begin{array}{c}\text { The automotive } \\
\text { industry in North } \\
\text { America }\end{array}$ & $\begin{array}{l}\text {-Supplier partnering } \\
\text {-Closer customer } \\
\text { relationship } \\
\text {-Cross-functional } \\
\text { teams }\end{array}$ & -Customer service & $\begin{array}{l}\text { Supply chain integration has } \\
\text { direct positive impact on } \\
\text { customer service. }\end{array}$ \\
\hline $\begin{array}{l}\text { Rosenzwei } \\
\text { g et } \\
\text { al.(2003) }\end{array}$ & $\begin{array}{l}\text { The consumer } \\
\text { products industry } \\
\text { in North } \\
\text { America, Europe, } \\
\text { Asia-Pacific, and } \\
\text { Latin America }\end{array}$ & $\begin{array}{l}\text {-Internal integration } \\
\text {-Integration with raw } \\
\text { materials suppliers } \\
\text {-Integration with } \\
\text { distributors and } \\
\text { retailers } \\
\text {-Integration with end } \\
\text { customers }\end{array}$ & $\begin{array}{l}\text {-Product quality } \\
\text {-Delivery } \\
\text { reliability } \\
\text {-Process } \\
\text { flexibility } \\
\text {-Cost leadership }\end{array}$ & $\begin{array}{l}\text { Manufacturers with high level } \\
\text { integration have better } \\
\text { conditions of product quality, } \\
\text { delivery reliability, process } \\
\text { flexibility, and cost leadership. }\end{array}$ \\
\hline $\begin{array}{l}\text { Swink et } \\
\text { al. (2007) }\end{array}$ & $\begin{array}{c}\text { Different } \\
\text { industries in } \\
\text { North America }\end{array}$ & $\begin{array}{l}\text {-Corporate strategy } \\
\text { integration } \\
\text {-Product-process } \\
\text { integration } \\
\text {-Strategic customer } \\
\text { integration } \\
\text {-Strategic supplier } \\
\text { integration }\end{array}$ & $\begin{array}{l}\text {-Cost } \\
\text {-Quality } \\
\text {-Delivery } \\
\text {-Process } \\
\text { flexibility } \\
\text {-New product } \\
\text { flexibility }\end{array}$ & $\begin{array}{l}\text { Integration with suppliers and } \\
\text { integration with customers } \\
\text { have no significant } \\
\text { relationship with competitive } \\
\text { capabilities. Corporate strategy } \\
\text { integration and } \\
\text { product-process integration } \\
\text { seem to be stronger drivers to } \\
\text { manufacturing capability } \\
\text { development. }\end{array}$ \\
\hline Kim & Different & -Integration with & -Cost leadership & Supply chain integration leads \\
\hline
\end{tabular}




\begin{tabular}{|c|c|c|c|c|}
\hline (2009) & $\begin{array}{l}\text { industries in } \\
\text { Japan and Korea }\end{array}$ & $\begin{array}{l}\text { suppliers } \\
\text {-Cross functional } \\
\text { integration within a } \\
\text { company } \\
\text {-Integration with } \\
\text { customers }\end{array}$ & $\begin{array}{l}\text {-Customer service } \\
\text {-Innovative } \\
\text { marketing } \\
\text { technology } \\
\text {-Differentiation }\end{array}$ & $\begin{array}{l}\text { to competitive capabilities in } \\
\text { Japanese companies. While, in } \\
\text { Korean companies with } \\
\text { smaller sizes competitive } \\
\text { capabilities in relation with } \\
\text { supply chain operational } \\
\text { capability lead to supply chain } \\
\text { integration. }\end{array}$ \\
\hline $\begin{array}{l}\text { Oghazi } \\
(2009)\end{array}$ & $\begin{array}{l}\text { Different } \\
\text { industries in } \\
\text { Sweden }\end{array}$ & $\begin{array}{l}\text {-Integration with } \\
\text { suppliers } \\
\text {-Integration within } \\
\text { the company } \\
\text {-Integration with } \\
\text { customers }\end{array}$ & $\begin{array}{l}\text {-Cost leadership } \\
\text {-Customer service } \\
\text {-Innovative } \\
\text { marketing } \\
\text {-Differentiation } \\
\text {-Focus strategy }\end{array}$ & $\begin{array}{l}\text { Supply chain integration } \\
\text { influences on competitive } \\
\text { capabilities positively. }\end{array}$ \\
\hline $\begin{array}{l}\text { Hosseini } \\
\text { Baharanchi } \\
\text { (2009) }\end{array}$ & $\begin{array}{l}\text { The automotive } \\
\text { industry in Iran }\end{array}$ & $\begin{array}{l}\text {-Internal integration } \\
\text {-Supply integration } \\
\text {-Customer integration }\end{array}$ & $\begin{array}{l}\text {-Product quality } \\
\text {-Product } \\
\text { innovation }\end{array}$ & $\begin{array}{l}\text { Integration with suppliers and } \\
\text { customers influences on } \\
\text { products quality and } \\
\text { innovation positively. Internal } \\
\text { integration has the weakest } \\
\text { relationship compared to other } \\
\text { aspects of integration with } \\
\text { product quality and has very } \\
\text { weak relationship with product } \\
\text { innovation. }\end{array}$ \\
\hline $\begin{array}{l}\text { Feng et } \\
\text { al.(2010) }\end{array}$ & $\begin{array}{l}\text { Different } \\
\text { industries in } \\
\text { China }\end{array}$ & $\begin{array}{l}\text {-Supplier } \\
\text { involvement } \\
\text {-Customer } \\
\text { involvement }\end{array}$ & $\begin{array}{l}\text {-Product quality } \\
\text {-Cost leadership } \\
\text {-Delivery } \\
\text { reliability } \\
\text {-Process } \\
\text { flexibility } \\
\text {-Customer service }\end{array}$ & $\begin{array}{l}\text { Participation with customers } \\
\text { has significant influence on } \\
\text { product quality, delivery } \\
\text { reliability, process flexibility, } \\
\text { and customer service, but no } \\
\text { influence on cost leadership. } \\
\text { Participation with supplier has } \\
\text { significant influence on cost } \\
\text { leadership, but has no } \\
\text { influence on product quality, } \\
\text { delivery reliability, process } \\
\text { flexibility, and customer } \\
\text { service. }\end{array}$ \\
\hline
\end{tabular}

Table 2. Cronbach's alpha internal consistency measure of reliability

\begin{tabular}{|l|l|c|c|}
\hline \multicolumn{2}{|l|}{ Variables } & Survey questions & Cronbach's alpha \\
\hline Supply chain integration & $\begin{array}{l}\text { Supply integration } \\
\text { Internal integration } \\
\text { Customer integration }\end{array}$ & $\begin{array}{c}\mathrm{Q}_{1}, \mathrm{Q}_{2}, \mathrm{Q}_{3}, \mathrm{Q}_{4}, \mathrm{Q}_{5}, \mathrm{Q}_{6} \\
\mathrm{Q}_{7}, \mathrm{Q}_{8}, \mathrm{Q}_{9}, \mathrm{Q}_{10}, \mathrm{Q}_{11}, \mathrm{Q}_{12}, \mathrm{Q}_{13} \\
\mathrm{Q}_{14}, \mathrm{Q}_{15}, \mathrm{Q}_{16}, \mathrm{Q}_{17}\end{array}$ & 0.91 \\
\hline Competitive capability & $\begin{array}{l}\text { Cost leadership } \\
\text { Differentiation }\end{array}$ & $\begin{array}{c}\mathrm{Q}_{18}, \mathrm{Q}_{19}, \mathrm{Q}_{20}, \mathrm{Q}_{21}, \mathrm{Q}_{22} \\
\mathrm{Q}_{23}, \mathrm{Q}_{24}, \mathrm{Q}_{25}, \mathrm{Q}_{26}, \mathrm{Q}_{27}\end{array}$ & 0.93 \\
\hline \multicolumn{2}{l|}{ The whole questionnaire } & $\mathrm{Q}_{1}-\mathrm{Q}_{27}$ & 0.97 \\
\hline
\end{tabular}


Table 3. Measurement and scaling of constructs

\begin{tabular}{|c|c|c|}
\hline Construct/Variable & Measurement items & Adapted from \\
\hline \multicolumn{3}{|c|}{ Supply Chain Integration (SCI) } \\
\hline \multirow{6}{*}{$\begin{array}{l}\text { Integration with } \\
\text { suppliers (INSU) }\end{array}$} & $\begin{array}{l}\text { INSU1: The level of information exchange with } \\
\text { suppliers through internet }\end{array}$ & $\begin{array}{l}\text { Flynn et al. (2010), Kim (2009), Oghazi (2009), } \\
\text { Boon-itt and Paul (2006), Zailani and Rajagopal } \\
(2005)\end{array}$ \\
\hline & $\begin{array}{l}\text { INSU2: The participation level of suppliers in } \\
\text { the process of procurement }\end{array}$ & $\begin{array}{l}\text { Flynn et al. (2010), Kim (2009), Oghazi (2009), } \\
\text { Boon-itt and Paul (2006) }\end{array}$ \\
\hline & $\begin{array}{l}\text { INSU3: The participation level of suppliers in } \\
\text { the process of production }\end{array}$ & $\begin{array}{l}\text { Flynn et al. (2010), Kim (2009), Oghazi (2009), } \\
\text { Boon-itt and Paul (2006) }\end{array}$ \\
\hline & $\begin{array}{l}\text { INSU4: The speed of ordering system to } \\
\text { procure materials }\end{array}$ & Flynn et al. (2010), Kim (2009), Oghazi (2009) \\
\hline & $\begin{array}{l}\text { INSU5: Helping suppliers with improving } \\
\text { their process to better meet firm needs }\end{array}$ & Flynn et al. (2010), Hosseini Baharanchi (2009) \\
\hline & $\begin{array}{l}\text { INSU6: Involving key suppliers in continuous } \\
\text { improvement programs }\end{array}$ & Feng et al.(2010), Swink et al.(2007) \\
\hline \multirow{7}{*}{$\begin{array}{l}\text { Internal Integration } \\
\text { (ININ) }\end{array}$} & $\begin{array}{l}\text { ININ1: Data integration among internal } \\
\text { functions }\end{array}$ & $\begin{array}{l}\text { Flynn et al. (2010), Kim (2009), Oghazi (2009), } \\
\text { Wong and Boon-itt (2008) }\end{array}$ \\
\hline & $\begin{array}{l}\text { ININ2: Real-time searching of the level of } \\
\text { inventory }\end{array}$ & Flynn et al. (2010), Kim (2009), Oghazi (2009) \\
\hline & $\begin{array}{l}\text { ININ3:Real time searching of the inventory } \\
\text { level }\end{array}$ & Flynn et al. (2010), Kim (2009), Oghazi (2009) \\
\hline & ININ4: Data integration in production process & Kim (2009), Oghazi (2009) \\
\hline & ININ5: Integrative inventory management & Flynn et al. (2010), Kim (2009) \\
\hline & $\begin{array}{l}\text { ININ6: The utilization of periodic } \\
\text { interdepartmental meetings among internal } \\
\text { function }\end{array}$ & Flynn et al. (2010), Kim (2009) \\
\hline & $\begin{array}{l}\text { ININ7: The use of cross functional teams in } \\
\text { process improvement. }\end{array}$ & Flynn et al. (2010), Oghazi (2009) \\
\hline \multirow{4}{*}{$\begin{array}{l}\text { Integration with } \\
\text { customers (INCU) }\end{array}$} & $\begin{array}{l}\text { INCU1:Follow-up with customers for } \\
\text { feedback }\end{array}$ & $\begin{array}{l}\text { Flynn et al. (2010), Kim (2009), Oghazi (2009), Feng } \\
\text { et al. (2010), Zailani and Rajagopal (2006) }\end{array}$ \\
\hline & $\begin{array}{l}\text { INCU2: The level of computerization for } \\
\text { customer ordering }\end{array}$ & Flynn et al. (2010), Kim (2009), Oghazi (2009) \\
\hline & $\begin{array}{l}\text { INCU3: The level of organic linkage with } \\
\text { customers through internet }\end{array}$ & $\begin{array}{l}\text { Flynn et al. (2010), Kim (2009), Zailani and } \\
\text { Rajagopal (2006) }\end{array}$ \\
\hline & $\begin{array}{l}\text { INCU4: The frequency of periodical contacts } \\
\text { with customers }\end{array}$ & Flynn et al. (2010), Kim (2009), Swink et al. (2007) \\
\hline \multicolumn{3}{|c|}{ Competitive capability (CC) } \\
\hline \multirow{5}{*}{$\begin{array}{l}\text { Cost Leadership } \\
\text { (CL) }\end{array}$} & $\begin{array}{l}\text { CL1: The capability to procure raw-material } \\
\text { consistently }\end{array}$ & Kim $(2009,2006)$, Oghazi (2009) \\
\hline & $\begin{array}{l}\text { CL2: Quality control capability in production } \\
\text { activity }\end{array}$ & Kim $(2009,2006)$, Oghazi (2009) \\
\hline & CL3: The capability to reduce production cost & Kim $(2009,2006)$, Oghazi $(2009)$ \\
\hline & CL4: Innovation of manufacturing process & Kim $(2009,2006)$, Oghazi (2009) \\
\hline & $\begin{array}{l}\text { CL5:The capability to reduce communication } \\
\text { and transaction costs }\end{array}$ & Oghazi (2009) \\
\hline \multirow{5}{*}{ Differentiation (DF) } & $\begin{array}{l}\text { DF1: The capability to develop and introduce } \\
\text { new product }\end{array}$ & $\operatorname{Kim}(2009,2006)$ \\
\hline & $\begin{array}{l}\text { DF2:The capability to differentiate product } \\
\text { through innovative design }\end{array}$ & Hosseini Baharanchi (2009) \\
\hline & $\begin{array}{l}\text { DF3:The capability to differentiate product } \\
\text { through quality }\end{array}$ & Hosseini Baharanchi (2009) \\
\hline & $\begin{array}{l}\text { DF4: The capability to distribute the product } \\
\text { broadly }\end{array}$ & Kim $(2009,2006)$, Oghazi(2009) \\
\hline & DF5:The capability to expand product line & Kim $(2009,2006)$, Oghazi(2009) \\
\hline
\end{tabular}


Table 4. Measurement model fit

\begin{tabular}{|c|c|c|c|c|c|c|}
\hline Latent variable & \multicolumn{2}{|c|}{ Item $^{a}$} & $\begin{array}{c}\text { Factor } \\
\text { Loading }\end{array}$ & $\begin{array}{c}\text { Error } \\
\text { Variance }\end{array}$ & $\mathrm{AVE}^{\mathrm{b}}$ & $\mathrm{CR}^{\mathrm{c}}$ \\
\hline \multirow{17}{*}{ Supply chain integration } & \multirow{6}{*}{ INSU } & SCI1 & 0.50 & 0.75 & \multirow{17}{*}{0.5007} & \multirow{17}{*}{0.9428} \\
\hline & & $\mathrm{SCI} 2$ & 0.52 & 0.73 & & \\
\hline & & $\mathrm{SCI} 3$ & 0.74 & 0.45 & & \\
\hline & & SCI4 & 0.58 & 0.66 & & \\
\hline & & SCI5 & 0.58 & 0.66 & & \\
\hline & & SCI6 & 0.91 & 0.17 & & \\
\hline & \multirow{7}{*}{ ININ } & SCI7 & 0.80 & 0.36 & & \\
\hline & & SCI8 & 0.92 & 0.15 & & \\
\hline & & SCI9 & 0.73 & 0.46 & & \\
\hline & & SCI10 & 0.81 & 0.34 & & \\
\hline & & SCI11 & 0.92 & 0.15 & & \\
\hline & & SCI12 & 0.61 & 0.63 & & \\
\hline & & SCI13 & 0.57 & 0.67 & & \\
\hline & \multirow{4}{*}{ INCU } & SCI14 & 0.72 & 0.48 & & \\
\hline & & SCI15 & 0.60 & 0.63 & & \\
\hline & & SCI16 & 0.66 & 0.57 & & \\
\hline & & SCI17 & 0.64 & 0.60 & & \\
\hline \multirow{10}{*}{ Competitive capability } & \multirow{5}{*}{$\mathrm{CL}$} & $\mathrm{CC} 1$ & 0.61 & 0.62 & \multirow{10}{*}{0.5213} & \multirow{10}{*}{0.9120} \\
\hline & & $\mathrm{CC} 2$ & 0.69 & 0.52 & & \\
\hline & & $\mathrm{CC} 3$ & 0.61 & 0.63 & & \\
\hline & & $\mathrm{CC} 4$ & 0.94 & 0.12 & & \\
\hline & & $\mathrm{CC} 5$ & 0.64 & 0.59 & & \\
\hline & \multirow{5}{*}{$\mathrm{DF}$} & CC6 & 0.92 & 0.16 & & \\
\hline & & $\mathrm{CC} 7$ & 0.85 & 0.27 & & \\
\hline & & $\mathrm{CC} 8$ & 0.70 & 0.51 & & \\
\hline & & CC9 & 0.35 & 0.87 & & \\
\hline & & CC10 & 0.72 & 0.48 & & \\
\hline $\begin{array}{l}\text { Note: }{ }^{a} \text { All measurement } \\
\text { chain integration and Con } \\
\text { b Average Variance Extra } \\
{ }^{c} \text { Composite reliability }=(2\end{array}$ & $\begin{array}{l}\mathrm{d}=\Sigma \lambda_{\mathrm{i}}^{2} / 1 \\
2 /\left[\left(\Sigma \lambda_{\mathrm{i}}\right)\right.\end{array}$ & $\begin{array}{l}\text { five-poir } \\
\text { bility we } \\
\left.\left.\Sigma \delta_{\mathrm{i}}\right)\right]\end{array}$ & $\begin{array}{l}\text { kert-type } \\
\text { chored ( }\end{array}$ & $\begin{array}{l}\text { es. Meas } \\
\text { tremely lo }\end{array}$ & ent scal & $\begin{array}{l}\text { or supply } \\
\text { ly high. }\end{array}$ \\
\hline
\end{tabular}

Table 5. Validity tests of measurement variables for each latent variable

\begin{tabular}{|l|c|c|c|c|c|c|}
\hline Latent variable & $\mathrm{X}^{2}$ Value & df & RMESA & GFI $^{\mathrm{a}}$ & AGFI $^{\mathrm{b}}$ & $\mathrm{NFI}^{\mathrm{c}}$ \\
\hline Supply chain integration & 36.59 & 32 & 0.041 & 0.93 & 0.91 & 0.96 \\
\hline Competitive capability & 35.33 & 13 & 0.074 & 0.91 & 0.89 & 0.93 \\
\hline $\begin{array}{l}\text { Note: } \chi^{2} / \mathrm{df} \leq 3, \text { RMSEA } \leq 0.08,{ }^{a} \text { Goodness of fit index }(\geq 0.9),{ }^{\mathrm{b}} \text { Adjusted goodness of fit index }(\geq 0.9),{ }^{\mathrm{c}} \\
\text { Normed fit index }(\geq 0.9), \mathrm{P} \leq 0.05 .\end{array}$
\end{tabular}

Table 6. AVE, CR, and squared inter-correlations for discriminant validity assessment

\begin{tabular}{|l|c|c|}
\hline & $(1)$ & $(2)$ \\
\hline Supply chain integration (1) & - & $0.358^{*}$ \\
\hline Competitive capability (2) & $0.358^{*}$ & - \\
\hline Average Variance Extracted (AVE) & 0.5007 & 0.5213 \\
\hline Composite reliability (CR) & 0.9428 & 0.9120 \\
\hline Note: ${ }^{*}$ Significance at the 0.01 level (two-tailed) & \\
\hline
\end{tabular}


Table 7. Variables descriptive data

\begin{tabular}{|l|l|c|c|c|c|c|c|}
\hline \multicolumn{2}{|c|}{$\begin{array}{l}\text { Supply } \\
\text { Chain }\end{array}$} & Mean & S.D & $(1)$ & $(2)$ & (3) & (4) \\
\cline { 2 - 9 } Integration & Supply Integration(1) & 3.0965 & 0.721 & & & & \\
\cline { 2 - 9 } $\begin{array}{l}\text { Competitive } \\
\text { Capability }\end{array}$ & Customer Integration(3) & 3.5927 & 0.771 & $0.662^{*}$ & & & \\
\cline { 2 - 9 } & Cost Leadership(4) & 3.6581 & 0.879 & $0.630^{*}$ & $0.693^{*}$ & & \\
\hline Dote: ${ }^{*}$ Significant & at the 0.01 level (two-tailed) & $0.451^{*}$ & $0.576^{*}$ & $0.642^{*}$ & \\
\hline
\end{tabular}

Table 8 . The main hypotheses testing results

\begin{tabular}{|l|l|c|l|l|}
\hline & Paths & $\begin{array}{c}\text { Standardized path } \\
\text { coefficient }\end{array}$ & t-values & Remarks \\
\hline $\mathrm{H}_{1}$ & $\begin{array}{l}\text { Supply Chain Integration } \rightarrow \text { Cost } \\
\text { Leadership }\end{array}$ & 0.86 & $6.10^{*}$ & Supported \\
\hline $\mathrm{H}_{2}$ & Supply Chain Integration $\rightarrow$ Differentiation & 0.73 & $6.53^{*}$ & Supported \\
\hline $\begin{array}{l}\text { Note: Fit indices: } \chi^{2}=174.36, \mathrm{df}=63, \text { P-value }=0.00000, \text { RMSEA }=0.078, \mathrm{GFI}=0.91, \mathrm{AGFI}=0.89, \mathrm{NFI}=0.93 . \\
{ }^{*} \mathrm{P} \leq 0.05\end{array}$ \\
\hline
\end{tabular}

Table 9. The sub-hypotheses testing results

\begin{tabular}{|c|l|c|c|l|}
\hline & Paths & $\begin{array}{c}\text { Standardized } \\
\text { path coefficient }\end{array}$ & t-values & Remarks \\
\hline $\mathrm{H}_{1 \mathrm{a}}$ & $\begin{array}{l}\text { Supply Integration } \rightarrow \text { Cost } \\
\text { Leadership }\end{array}$ & -0.73 & -2.20 & Supported \\
\hline $\mathrm{H}_{2 \mathrm{a}}$ & $\begin{array}{l}\text { Supply Integration } \rightarrow \\
\text { Differentiation }\end{array}$ & -0.77 & -2.33 & Supported \\
\hline $\mathrm{H}_{1 \mathrm{~b}}$ & $\begin{array}{l}\text { Internal Integration } \\
\text { Leadership }\end{array}$ & -0.41 & -0.76 & Not Supported \\
\hline $\mathrm{H}_{2 \mathrm{~b}}$ & $\begin{array}{l}\text { Internal Integration } \\
\text { Differentiation }\end{array}$ & -0.57 & -0.93 & Not Supported \\
\hline $\mathrm{H}_{1 \mathrm{c}}$ & $\begin{array}{l}\text { Customer Integration } \\
\text { Leadership }\end{array}$ & 0.84 & 3.22 & Supported \\
\hline $\mathrm{H}_{2 \mathrm{c}}$ & $\begin{array}{l}\text { Customer Integration } \\
\text { Differentiation }\end{array}$ & 0.87 & 3.29 & Supported \\
\hline
\end{tabular}

Note: Fit indices: $\chi^{2}=532.15, \mathrm{df}=315, \mathrm{P}$-value $=0.00000, \mathrm{RMSEA}=0.071, \mathrm{GFI}=0.91, \mathrm{AGFI}=0.87$, $\mathrm{NFI}=0.94$.

${ }^{*} \mathrm{P} \leq 0.05$

Table 10. The new hypotheses testing results

\begin{tabular}{|l|ll|c|c|l|}
\hline & Paths & $\begin{array}{c}\text { Standardized } \\
\text { path coefficient }\end{array}$ & t-values & Remarks \\
\hline $\mathrm{H}_{3 \mathrm{a}}$ & Internal Integration $\rightarrow \quad$ Supply Integration & 0.93 & 4.48 & Supported \\
\hline $\mathrm{H}_{3 \mathrm{~b}}$ & Internal Integration $\rightarrow \quad$ Customer Integration & 0.92 & 7.02 & Supported \\
\hline $\begin{array}{l}\text { Note: Fit indices: } \chi^{2}=588.89, \mathrm{df}=318, \text { P-value }=0.00000, \text { RMSEA }=0.075, \mathrm{GFI}=0.92, \mathrm{AGFI}=0.90, \mathrm{NFI}=0.96 . \\
{ }^{*} \mathrm{P} \leq 0.05\end{array}$ \\
\hline
\end{tabular}




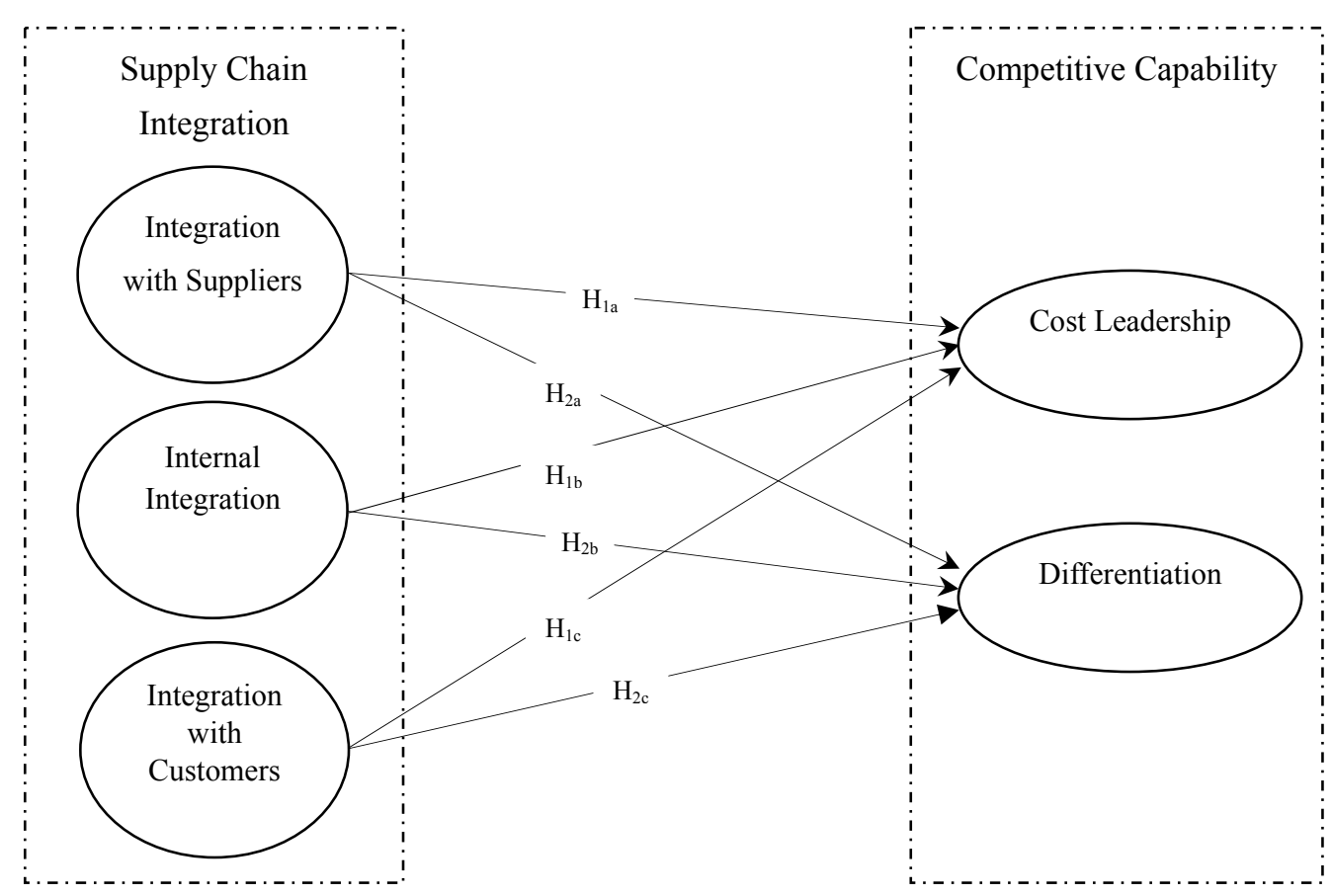

Figure 1. Research Conceptual Model

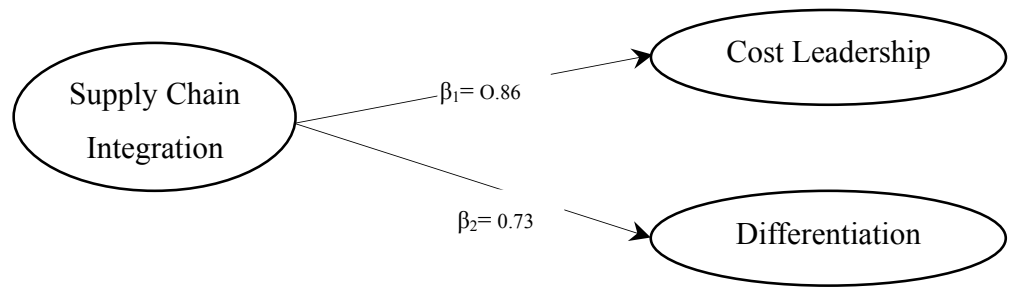

Figure 2. The main hypotheses with path coefficients

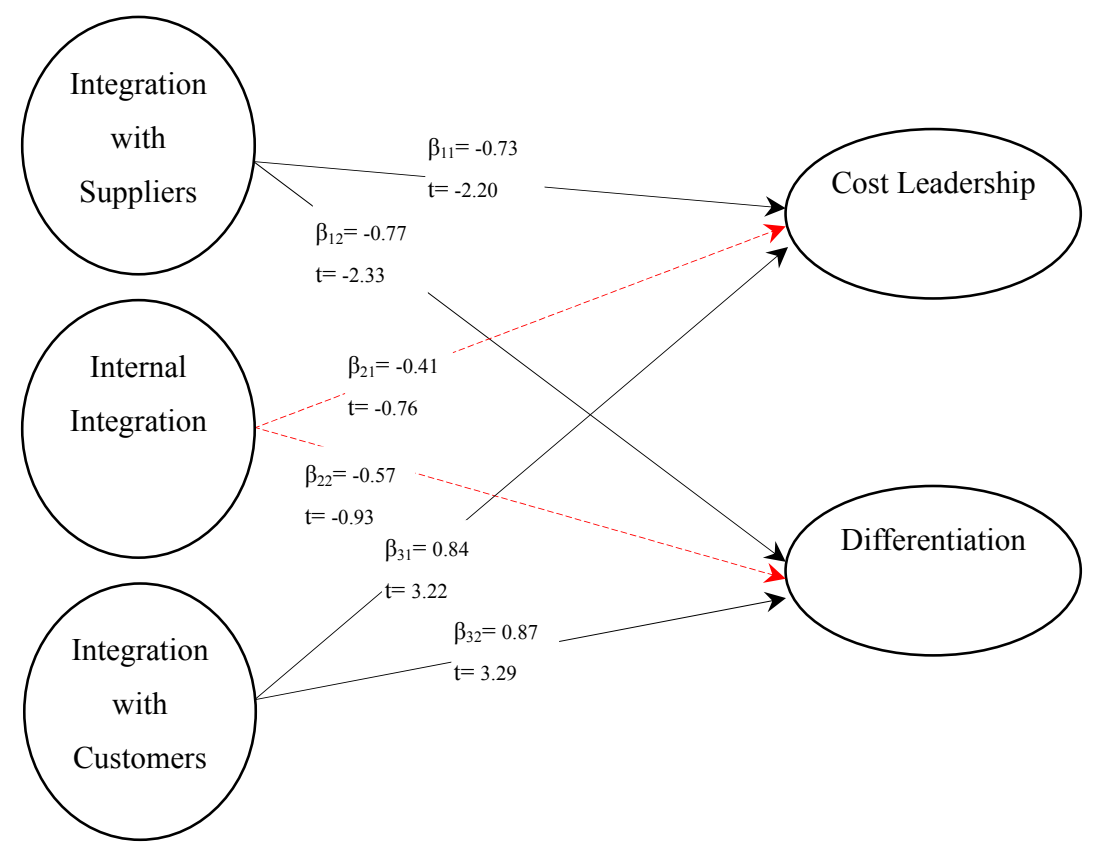

Figure 3. The sub-hypotheses model with path coefficients 


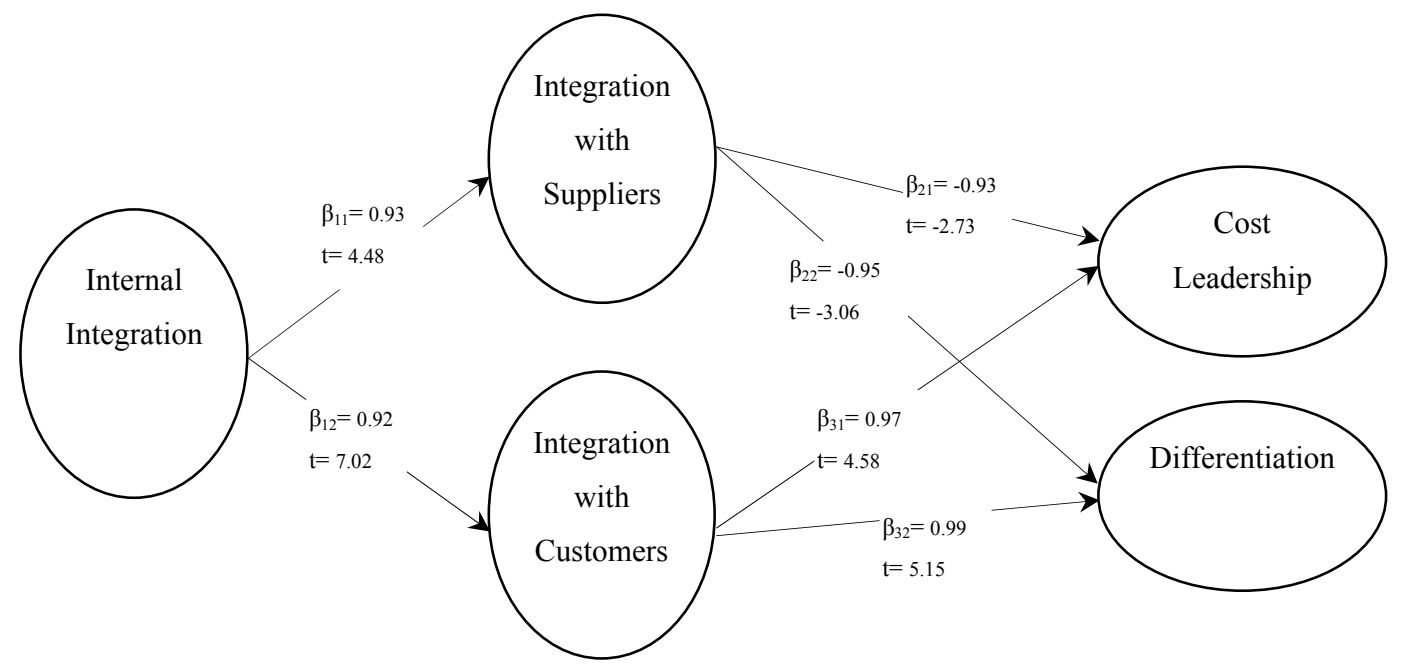

Figure 4. The modified model with path coefficients

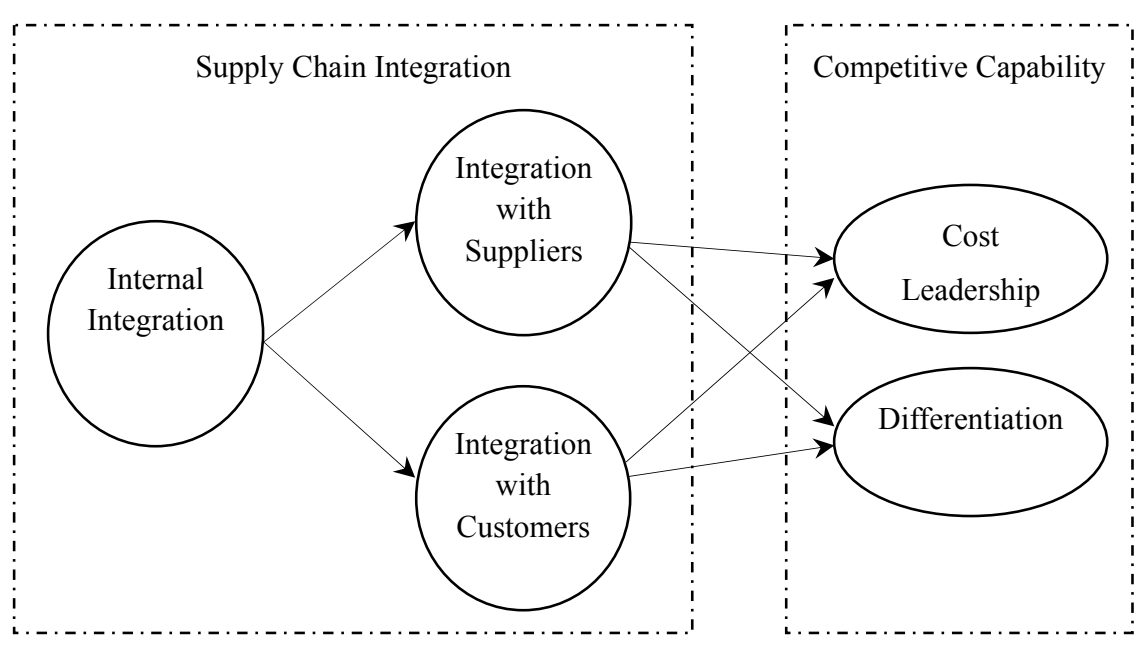

Figure 5. The final model 